\title{
Role of Types of Flexible Work Options on Organizational Performance of Listed Companies in the Nairobi Securities Exchange in Kenya
}

\author{
Racheal Muthoni Mwangi ${ }^{1 *}$, Prof. M. M. Theuri ${ }^{2}$, Dr. Anne Sang ${ }^{3}$ \\ ${ }^{1}$ Post graduate student, Dedan Kimathi University of Technology, Kenya \\ ${ }^{2,3}$ Lecturer, Dedan Kimathi University of Technology, Kenya
}

*Corresponding Author: Racheal Muthoni Mwangi, Post graduate student, Dedan Kimathi University of Technology, Kenya

\begin{abstract}
:
Purpose: The purpose of the study was to establish the role of types of flexible work options on organizational performance of listed companies in the Nairobi Securities Exchange in Kenya

Methodology: Descriptive and correlation survey research designs were employed. Stratified simple random sampling technique was applied in drawing a sample of 224 respondents from population of 534 top managers of the ten stratums of the NSE listed companies in Kenya

Results: The findings indicated that the goodness of fit for the regression between organizational performance and types of flexible work options of companies listed in NSE was satisfactory. An $R$ squared of 0.245 showed that $24.5 \%$ of the variances in the acceptance of the types of Flexible work options by NSE listed companies are explained by the variances in the organizational performance.

Policy recommendation: It is recommended that different types of flexible work options could be fully adopted and implemented to enhance company performance. This would be by formulating well written down polices that govern the selection and application of various flexible work options. Companies could sensitize staff on the availability of the various flexible work options and guide employees on selection of these options based on the applicability and nature of the job, and the practice implemented. This process should be monitored, evaluated and reviewed to ensure the company performance is enhanced.
\end{abstract}

Keywords: Types offlexible work options, organizational performance, Nairobi Securities Exchange

\section{INTRODUCTION}

As the global business competition war intensifies, there is an increasing need for companies to adopt innovative HR strategies and adapt a variety of changes in order to remain competitive in their various markets lest they are deemed irrelevant (Winder, 2009). Formal work flexibility have been an important step toward increasing work life balance and enhancing performance. The understanding of work flexibility dates back to year 2010 when the workplace flexibility comprehensive policy solution was released in America to expand the American's access to work flexibility. Work flexibility generally refer to a practice in organizations where employees are able to choose when they work and where they work from so long as they fulfil their working obligations in doing so (Grzywacz, Carlson\& Shulkin, 2008).

Flexible work options are among the many Work-Life Balance (WLB) initiatives being advanced by many organizations as they seek to enable their employees reconcile their work life and family responsibilities (Ruhm, 2005). The work arrangement provides options other than the traditional workplace expectation that employees must work continuously and full-time and do so consistently in the office. Kossek and Lee (2011) argues that, this focuses on relatively short-term personal situations while ignoring longer-term career implications. However, the implementation of flexible working hours is an effective stage to increase productivity without increasing the work force (Cushway, 1994). As business continue to rapidly adapt to the changing business conditions, smart organizations are keenly seeking to reduce costs incurred in terms of work space and maximize profits. Given that 
employment situations all over the world has become more competitive and unstable, many companies and organizations have inclined to present more flexible employment conditions, focusing on prospective tribulations (such as lower demand of the market) and the possibility of lay-offs (OECD, 2002). Flexible working arrangements are increasingly offered by organizations in order to remain competitive through the recruitment and retention of top performing employees. The employer is more concerned with performance rather than presence of employees at work place and flexible working is becoming a standard element of normal business practice, driven by employee demand for more autonomy in managing their work-life balance, by improved technology.

The Employment Act (2007) primarily governs the employment relationship in Kenya. The Act defines the fundamental rights of employees, sets out the basic conditions of employment and regulates matters dealing with the employment of children. The Employment Act (2012) also provides a number of work life balance initiatives that relate to the employment relationship. The Kenyan work space has also changed drastically over the years. A new crop of generation (millennial) has morphed the work place, these are the working force in their twenties and early thirties. The young people value a lot of work flexibility, they for instance do not care what time they report to work provided they get the work done. They will search for other job opportunities if they sense they are too restricted by the work schedule (IHRM, 2016).

\subsection{Problem Statement}

The government and the private sector have invested heavily in creating an enabling environment for doing business in Kenya and, indeed, some companies have performed exceedingly well as a result. Several companies, however, are experiencing declining productivity and some have even been delisted from the NSE in the last decade. In Kenya there has been a growing concern on companies' productivity in the face of global competitiveness and the 24 hours economy. Often, this has resulted to staff lay offs, down sizing, companies being under receivership and even companies closures. In this regard, companies in Kenya will need to device ways and strong performance strategies in order to remain competitive in the global market. Momentous efforts to revive the ailing and liquidating companies have focused on organizational restructuring. However, managers and practitioners still lack adequate guidance for attaining optimal performance yet many of the problems experienced by the companies put under statutory management were largely attributed to employees' output. There is also rapid change in the world of work today for instance, the millennial present varying work demands and seek autonomy from their employers.

There is however, a significant divergence on exactly how various working time arrangements influence organizational performance and if directly or indirectly.Most of the studies have been conducted in developed countries and it is not clear whether the same can be replicated in the developing countries due to cultural and geographical differentials. Further, from the literature review, it is evident that there is scanty literature on work flexibility and its influence on organizational performance in NSE listed companies in Kenya. This study sought to establish the role of the types of flexible work arrangements on organizational performance in the companies listed in the NSE.

\subsection{Research Objective}

- To assess the role of type of flexible work options on organizational performance of listed companies in the Nairobi Securities Exchange

\section{LITERATURE REVIEW}

\subsection{Theoretical Framework}

The study relied on flexible work arrangement model by Al Rajudi (2012). The flexible work arrangement model identifies the flexible work arrangements components and link them to employee productivity that leads to the performance of the organization.

\subsection{Empirical Review}

Types of flexible work practices was measured by reduced absenteeism, employee loyalty, staff retention, and competitive advantange (Kossek and Van Dyne, 2008). A decrease in employees' 
Role of Types of Flexible Work Options on Organizational Performance of Listed Companies in the Nairobi Securities Exchange in Kenya

absenteeism and work-related stress enables workers to give optimum attention to their work (Baltes et al., 1999). Flexible work options is defined as an alternative to the standard working day where employees are able to choose when they work and where they work from so long as they fulfill their working obligations in doing so (Rau \& Hyland, 2002: Grzywacz, Carlson, \& Shulkin, 2008). The common flexibility arrangements includes; flexi-time, permanent part-time work, absence autonomy, job sharing, compressed work weeks, reduced schedule, telework, extra vacation days, limited schedule of meetings (meetings cannot be scheduled too late at the end of the day), flexible holidays and keeping with the schedule (employees work the mandatory 8 hours a day and do not extend their schedules longer (Rau et al., 2002; Hartel et al., 2007).On the other hand, employees benefit from the flexible arrangements; this is mainly by re-energizing themselves, having extra time to balance work and family life as well as save the workers too much stress and burn outs and reduce family - work conflicts (Christine, 2005). Flexible work arrangements help an organization to enjoy the benefits of fully engaged employees by having minimal absenteeism, high staff morale and high performance (Hebson, 2004).

When Flexible Work Arrangements (FWA) are offered by the organization, it does not necessarily mean that all employees have equal access to FWA. In fact, the difference between the percent of employers that provide flexibility to "all" employees versus "some" employees is striking. For example, 2012 National Study of Employers (Matos \& Galinsky, 2012) reported that 63 percent of employers allowed some employees to work at home occasionally; only 6 percent of employers allowed most or all of their employees to do so. Moreover, not all employees with access to FWA use the options (Kirby \& Krone, 2002).Working from home is the most common example. In a metaanalysis of telecommuting conducted by Gajendran and Harrison (2007), home was the primary location in nearly all the studies included. A third way to provide workplace flexibility is changing the number of work hours, which usually includes reduced work hours and job sharing. Unlike employees who use flexi-time, compressed workweek, or working from home, employees who use reduced work hours and job sharing often change their employment status from full time to part time. Employees might not be fully aware of the benefits to which they are entitled, because of the visibility or relevance of FWA to them (Bowen \& Ostroff, 2004; Prottas, Thompson, Kopelman, \& Jahn, 2007). Recently, some scholars have looked at individual level factors and suggested that individual experiences with FWA have stronger impacts on employee work outcomes than the presence of FWA at the organizational level (Allen, Johnson, Kiburz, \& Shockley, 2013; Eaton, 2003).

Flexibility in the scheduling of hours usually includes flexi-time, compressed workweek, and scheduling of breaks and overtime. Flexi-time means that employees work a certain number of core hours, but they can vary their start and stop times as long as they work the equivalent of a full work week. Compressed workweek means working longer hours each day to reduce the number of days in a workweek. Flexibility in the place of work allows employees to perform tasks at places other than their primary workplace during their work schedule. Working from home is the most common example. Flex-time, compressed workweek, working from home, job sharing, and reduced work hours have been increasingly implemented by employers as responses to the conflicts between employees' work and personal life. According to 2012 National Study of Employers (Matos \& Galinsky, 2012), the majority of employers have adopted flexible work arrangements (FWA) that allow employees to better manage their working hours and locations. For example, 77 percent of employers reported that they have offered flexible work time, and 63 percent reported flexible work location.

However, employees in the banking sector in Kenya have to put in more work characterized by high level commitments, deadlines and unpredictable peaks and troughs during the course of the working time (Mukururi \& Ngari, 2014). Most major banks have their busiest branches in the Central Business Districts hence employees working in the central business district work longer hours, their work is more complex and intensified hence experiencing a lot of work pressure and creating a culture of poor work life-balance (Mukururi, 2014)Kenya's banking sector comprises of 43 commercial banks with 1,523 branches (CBK, 2015). Employees in these Kenyan banks need to play a great role of delivering quality services and creating a pool of satisfied customers. Despite their key role, there persist work life policies and challenges in the implementation of existing policies by Kenyans organizations. Kenyan Strathmore business school reported mixed response on the existence and extent of adoption of work life initiatives by Kenya's organizations (Mukururi \& Ngari, 2014). 
Role of Types of Flexible Work Options on Organizational Performance of Listed Companies in the Nairobi Securities Exchange in Kenya

Social exchange theory (Blau, 1964-1999) can be used to explain the mechanisms through which perceived availability of work flexibility promote the desired work outcomes from the employees. When the organization offers work flexibility to certain employee groups, the organization demonstrates that it values these employees' contributions and cares about their well-being. In return, employees who perceive work flexibility to be available and receive these signals from the organization feel obligated to reciprocate and care about the organization's success, which leads to increased job satisfaction and organizational commitment.

In the context of this study, the researcher points out that the implications the social exchange theory is that work flexibility may have divergent consequences depending on the extent to which managers interpret. This could be from a point of self-serving and company serving for employees within the framework of the flexible work arrangement practices and therefore, the researcher argues that social exchange theory was applicable to the type of work flexibility for example, part-time, job sharing and compressed work week.

\subsection{Conceptual Framework}

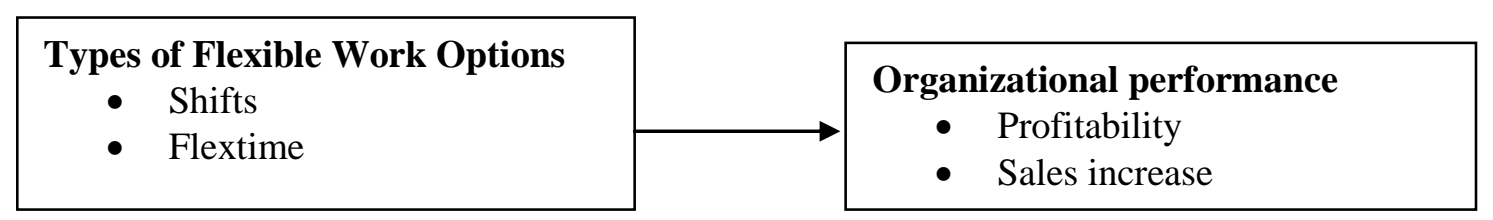

Figure1. Conceptual Framework

\section{Methodology}

The study adopted descriptive and correlation survey research designs. The researcher used stratified simple random sampling technique to draw a sample of 224 respondents from a population of 534 top managers of the ten stratums of the NSE listed companies in Kenya. Primary data was obtained by use of questionnaires. Reliability of the measures in the instrument was tested using Cronbach's alpha.

\section{RESULTS FINDINGS}

\subsection{Response Rate}

This refers to the percentage of subjects who respond to questionnaires. Previous studies have demonstrated that a response rate of $50 \%$ is adequate for analysis and reporting. Specifically, Mugenda \& Mugenda (2003) assert that 50\% is adequate, $60 \%$ is good and above $70 \%$ is very good. The number of questionnaires administered totaled to 224 those that were properly filled and returned were 162 . This represented $72 \%$ response rate. The achieved response was more than $70 \%$ which was considered very good.

Table1. Response Rate

\begin{tabular}{|l|l|l|}
\hline Response & Frequency & Percent \\
\hline Successful & 162 & 72 \\
\hline Unsuccessful & 62 & 28 \\
\hline Total & $\mathbf{2 2 4}$ & $\mathbf{1 0 0}$ \\
\hline
\end{tabular}

\subsection{Descriptive Results}

The objective of the study was to establish the role of types of flexible options on organizational performance.

Table2. Types of Flexible work options

\begin{tabular}{|l|l|l|l|l|l|}
\hline \multicolumn{1}{|c|}{ Statement } & $\begin{array}{l}\text { Strongly } \\
\text { Disagree }\end{array}$ & Disagree & Neutral & $\begin{array}{c}\text { Agree } \\
\text { Strongly } \\
\text { Agree }\end{array}$ \\
\hline $\begin{array}{l}\text { In this company, home connection or telecommuting has } \\
\text { enabled employees to work remotely and acquire new } \\
\text { experience }\end{array}$ & $6.80 \%$ & $4.90 \%$ & $6.20 \%$ & $45.10 \%$ & $37.00 \%$ \\
\hline $\begin{array}{l}\text { In this company, part-time working has enabled staff to } \\
\text { engage in their own career development }\end{array}$ & $0.60 \%$ & $4.30 \%$ & $5.60 \%$ & $43.80 \%$ & $45.70 \%$ \\
\hline
\end{tabular}


Role of Types of Flexible Work Options on Organizational Performance of Listed Companies in the Nairobi Securities Exchange in Kenya

\begin{tabular}{|l|l|l|l|l|l|}
\hline $\begin{array}{l}\text { Employees are now enabled to work on shifts or job sharing } \\
\text { because of the company adopting the flexible work program }\end{array}$ & $9.90 \%$ & $11.1 \%$ & $4.30 \%$ & $35.80 \%$ & $38.90 \%$ \\
\hline $\begin{array}{l}\text { My company benefits from compressed work weeks due to } \\
\text { provision of services for long and varied times }\end{array}$ & $4.30 \%$ & $9.90 \%$ & $0.00 \%$ & $70.40 \%$ & $15.40 \%$ \\
\hline $\begin{array}{l}\text { Flextime has helped employees to manage burn outs and } \\
\text { work related stress }\end{array}$ & $4.30 \%$ & $4.30 \%$ & $8.60 \%$ & $39.50 \%$ & $43.20 \%$ \\
\hline
\end{tabular}

The study sought to establish how home connection or telecommuting has enabled employees to work remotely and acquire new experience in the NSE listed companies. Home connection was an essential element of types of flexible work options. Results on table 2 indicate that a majority, $82 \%$ of the respondents agreed with the statement that in their company, home connection or telecommuting had enabled employees to work remotely and acquire new experience, $12 \%$ of the respondents disagreed with the statement while $6 \%$ were undecided on the statement.

On part-time, the study sought to establish the extent to which part- time working in the companies in NSE had enabled employee to engage in their own career development. Part-time working was crucial as a type of flexible work option. The results on table 2 indicated that the majority of the respondents $89 \%$ agreed with the statement that part time working has enabled staff to engage in their own career development, $5 \%$ of the respondents disagreed with the statement while $6 \%$ of the respondents were undecided on the statement.

Further, on shifts, the study sought to establish if the companies in the NSE enable employees to work on shifts or job sharing. Shifts was crucial to types of work options. The results on table 2 indicate that $75 \%$ agreed with the statement that in their company, employees are enabled to work on shifts or job sharing because of the company adopting flexible work program, $21 \%$ of the respondents disagreed with the statement while $4 \%$ were neutral on the statement. Messenger (2011) in the study of work flexibility notes that interestingly, small companies were nearly four times more likely to offer job sharing to all or most employees than large companies. The findings implied that companies listed in the NSE make use of the different types of flexible work options and job sharing has contributed positively to type of flexible work options that have positively contributed to organizational performance.

On the statement of compressed work weeks, the study sought to establish the extent to which companies listed in the NSE benefit from compressed work weeks. Compressed work week was a crucial as a type of work flexibility. The results on table 2 indicated that $86 \%$ of the respondents agreed with the statement that their company benefited from compressed work weeks due to provision of services for long and varied times while $14 \%$ of the respondents disagreed on the statement.

Further, the study sought to establish the extent to which flextime had helped employees in the NSE listed companies to manage burn outs and work related stress. Flextime was an important component in flexible work options. The results on table 2 indicated that $82 \%$ of the respondents agreed with the statement that flextime had helped employees to manage burn outs and work related stress, $9 \%$ of the respondents disagreed with the statement while $9 \%$ was undecided on the statement.

\subsection{Relationship between Types of Flexible Options and Organizational Performance}

A correlation test analysis was carried out between the dependent variable (organizational performance) and the independent variable type of flexible work options. From the results on table 4.28 , acceptance of organizational performance was moderately but positively correlated with the type of flexible work options. The results further reveals that any positive change in the type of flexible work options on organizational performance, led to an increase in acceptance of organizational performance.

Table3. Relationship between Types of FWOs and Organizational Performance

\begin{tabular}{|l|l|l|l|}
\hline \multicolumn{1}{|c|}{ Variable } & \multicolumn{1}{|c|}{$\begin{array}{c}\text { Organizational } \\
\text { Performance }\end{array}$} & $\begin{array}{c}\text { Types of Flexible } \\
\text { work options }\end{array}$ \\
\hline \multirow{2}{*}{$\begin{array}{l}\text { Organizational } \\
\text { Performance }\end{array}$} & Pearson Correlation & & \\
\cline { 2 - 4 } $\begin{array}{l}\text { Type of Flexible work } \\
\text { options }\end{array}$ & Sig. (2-tailed) & 1 & 1 \\
\hline **. Correlation is significant at the 0.01 level (2-tailed). & 0.495 & \\
\cline { 2 - 4 } & Sig. (2-tailed) & .000 & \\
\hline
\end{tabular}


Role of Types of Flexible Work Options on Organizational Performance of Listed Companies in the Nairobi Securities Exchange in Kenya

Table 4 shows the goodness of fit for regression between the variables.

Table4. Model Summary for Types of Flexible work options

\begin{tabular}{|l|l|l|l|l|}
\hline \multicolumn{4}{|l|}{ Model Summary } \\
\hline Model & R & R Square & Adjusted R Square & Std. Error of the Estimate \\
\hline 1 & $.495^{\mathrm{a}}$ & .245 & .240 & 3.27433 \\
\hline
\end{tabular}

Predictors: (Constant), Types of FWOs

A regression analysis was carried out to determine if types of Flexible work options was a significant determinant of organizational performance in the companies listed in NSE in Kenya. The regression results indicated that the goodness of fit for the regression between organizational performance and types of Flexible work options was satisfactory. An R squared of 0.245 indicates that $24.5 \%$ of the variances in the acceptance of the types of Flexible work options by NSE listed companies are explained by the variances in the organizational performance. The correlation coefficient of $49.5 \%$ indicates that the combined effect of the predictor variables have a strong and positive correlation with organizational performance.

Table5. ANOVA for Types of FWOs

\begin{tabular}{|l|l|l|l|l|l|}
\hline Indicator & Sum of Squares & Df. & Mean Square & F & Significance \\
\hline Regression & 555.908 & 1 & 555.908 & 51.851 & .000 \\
\hline Residual & 1715.399 & 160 & 10.721 & & \\
\hline Total & $\mathbf{2 2 7 1 . 3 0 7}$ & $\mathbf{1 6 1}$ & & & \\
\hline
\end{tabular}

From the study, the model was significant as indicated by an F statistic of 51.851 that was supported by a p-value of 0.000 . The results indicated that the probability value was less than the conventional probability of $(0.05)$ hence this was an indication that since the probability value was 0.000 , there was a very low probability that the statement "the overall model was insignificant" was true. It was therefore concluded that the statement was untrue. The regression coefficient of the independent variable (types of Flexible work options) was carried out. Table 6 shows the regression coefficient of types of Flexible work options.

Table6. Regression Coefficient for Types of Flexible work options

\begin{tabular}{|l|l|l|l|l|}
\hline Variable & Beta & Std. Error & T & Significance \\
\hline Constant & 9.731 & 1.085 & 8.972 & 0.000 \\
\hline Types of FWOs & 0.419 & 0.058 & 7.201 & 0.000 \\
\hline
\end{tabular}

The results indicated that types of flexible work options are statistically significant in explaining organizational performance of companies listed in the NSE.

\section{SUMMARY OF FINDINGS, CONCLUSION AND RECOMMENDATIONS}

\subsection{Summary of Findings}

The study sought to establish the role of types of flexible work options on organization performance in companies listed in the Nairobi Securities Exchange (NSE), in Kenya. The results indicated that types of flexible work options had significant role on organizational performance.

Types of flexible work option indicators included; shifts, home connection, part-time, flextime and compressed work week. The elements that measured types of flexible work options included whether; home connection or telecommuting had enabled employees to work remotely and acquire new experience, part-time working had enabled staff to engage in their own career development, employees were enabled to work on shifts or job sharing because of the company adopting the flexible work program, companies had benefits from compressed work weeks due to provision of services for long and varied times and flextime has helped employees to manage burn outs and work related stress.

The null hypothesis was rejected by regression results. This meant that the types of flexible options had a significant relationship with organizational performance. 
Role of Types of Flexible Work Options on Organizational Performance of Listed Companies in the Nairobi Securities Exchange in Kenya

\subsection{Conclusion}

The study concluded that companies listed in NSE used different type of flexible work options. The study revealed that, having the job sharing pattern of work is advantageous to any organization because the employees are able to share their ideas regarding work; two heads are better than one, integrations of various forms of flexible work options had given employees a wide option from which employees can choose what best applies in their case and this became a motivator to employees and contributed to increased output, the adoption of supportive flexible work program led to a more dedicated staff and enhanced the organizational performance. The findings were supported by the positive and significant relationship between type of flexible work options and organizational performance.

\subsection{Recommendations of the Study}

The study suggest that type of flexible work options such as shifts or job sharing, part-time, home connection, flextime and compressed work weeks should be fully adopted by the companies listed in the NSE as doing so would lead to enhance performance.

\section{REFERENCES}

[1] Al-Rajudi O. (2012). Impact of FLEXIBLE WORK on Workers' Productivity in Information and Communication Technology sector. An empirical study of Gaza Strip ICT firms.

[2] Anderson, T. 2004. "Overwork robs workers' health: interpreting OSHA's general duty clause to prohibit long work hours", in New York City Law Review, Vol. 7, Spring, No. 85.

[3] Annual Report, (2009).NSE Annual Report. Retrieved 1st May 2013 from www.nse.com.

[4] Armstrong, M. (2011). A handbook of Human Resource Management practices (10th ed).London \& Philadelphia: Kogan Page Limited.

[5] Baltes, B., Briggs, T. Wright, J. Neuman, G. (1999). Flexible and compressed workweek schedules: A meta-analysis of their effects on work-related criteria. Journal of Applied Psychology, (Vol. 84, No. 4, pp. 496-513).

[6] Bloom, N.; Van Reenen, J. (2006). "Management Practices, Work-Life Balance, andProductivity: A Review of Some Recent Evidence", in Oxford Review of Economic Policy, Vol. 22, Issue

[7] Cooke, P. (2012). Social capital and market interactions: An analysis of firm performance in UK regions. Review of Social Economy, 65(1), 79-106.Hawking, S. (1996)."The Illustrated A Brief History of time "(Updated and expanded.New York

[8] Cushway, B. (1994). Flexible working Practices: The Controversy and Evidence. In C. Brewster, \& Hegewisch, A. (Eds.), Policy and Practice in European Human Resource Management:London.

[9] Den, Dulk, L. \& Peper, B. (2007). Working Parents' use of work-life policies. Sociologia, Problemas e Práticas, 53, 51-70.

[10] Feldman, D. C. (1990). Re-conceptualizing the nature and consequences of part-time work. The Academy of Management Review, 15(1), 103-112.

[11] Friedman, S.D., Christensen, P. and DeGroot, J. (1998) 'Work and life: the end of the zero sum game', Harvard Business Review, November-December, vol 76

[12] Grzywacz, J.G.; Carlson, D.; Shulkin, S. (2008). "Schedule flexibility and stress: Linking formal flexible arrangements and perceived flexibility to employee health", in Community, Work \& Family, Vol. 11, No. 2, pp. 199-214.

[13] Halpern, D. F. (2004). Public policy, work, and families: The report of the APA presidential initiative on work and families. Washington, DC: American Psychological Association.

[14] Kossek, E., \& Hammer, L. (2008). Work/Life training for supervisors gets big results. Harvard Business Review, November, p. 36.

[15] Kossek, E.E. \& Lee, M.D. (2011). Implementing a Reduced-Workload Arrangement to Retain High Talent: A Case Study. The Psychologist-Manager Journal, (Vol. 11, No. 1, pp. 49-64).

[16] Mugenda, O. M. and Mugenda, A. G (2003). Research Methods: Quantitative and Qualitative Approaches. Nairobi: Acts Press. 
Role of Types of Flexible Work Options on Organizational Performance of Listed Companies in the Nairobi Securities Exchange in Kenya

[17] NSE Handbook (2013). Nairobi Security Exchange Limited Handbook. 2008-2012.Retrieved on 26 November 2013 from www.African -exchange org/download/library/NSE handbook.pdf

[18] Ruhm, C.J. (2005). "How Well Do Government and Employer Policies Support Working Parents?", Workforce-Workplace Mismatch? Work,Family, Health and Well-Being Mahway, NH, Lawrence Erlbaum Press.

[19] Winder, K.L. (2009). "Flexible Scheduling and the Gender Wage Gap", in The B.E. Journal of Economic Analysis \& Policy, Vol. 9, No. 1 (Topics), Article 30.

\section{AUTHORS' BIOGRAPHY}

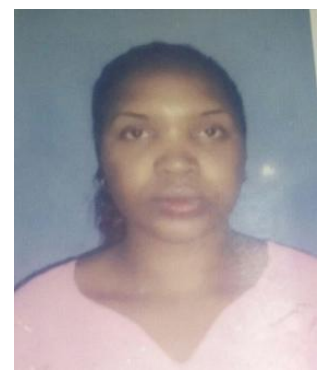

Racheal Muthoni Mwangi is a Human Resource Management Consultant and Practitioner in charge of Human Resource Development at the Kenya Institute of Curriculum Development. She has a passion for Human Resource Management and Development that is propelled by quality management systems that advocates for high level work practices and effective performance for quality delivery of services. Racheal's specialization is in Human Resource Management where she has undertaken activities on knowledge management and transfer of skills and competencies for enhanced work performance in organizations in the field of Human Resource Management.

Citation: Racheal Muthoni Mwangi. Prof. M. M. Theuri, Dr. Anne Sang "Role of Types of Flexible Work Options on Organizational Performance of Listed Companies in the Nairobi Securities Exchange in Kenya" International Journal of Humanities Social Sciences and Education (IJHSSE), vol 5, no. 2, 2018, pp. 58-65. doi: http://dx.doi. org/10.20431/2349-0381.0502007.

Copyright: () 2018 Authors. This is an open-access article distributed under the terms of the Creative Commons Attribution License, which permits unrestricted use, distribution, and reproduction in any medium, provided the original author and source are credited. 